\title{
HOLOKAUST I ODRODZENIE. METAMORFOZY KOLORU W MALARSTWIE ARTYSTY ŻYDOWSKIEGO - OCALONEGO ALEKSANDRA BOGENA (1916-2010). WYBRANE PRZYKLADY
}

\section{Holocaust and Rebirth: Metamorphoses of Colours in the Work of Jewish Artis- Holocaust Survivor Aleksander Bogen (1916-2010) \\ Abstract}

According to my research, between 1946 and 1950 in Poland, there were about 40 active visual artists who were Holocaust survivors. One of them was Alexander Bogen (1916-2010) from Vilnius. A partisan, he participated in the action of rescuing people from the ghetto. He spent the years 1947-1951 in Łódź. He emigrated to Israel, where he is considered one of the most prominent colourists. Although Bogen did not intend to take up the Holocaust as his subject, one could find its symbolical representations in his oeuvre. The most significant include a group of partisans, a girl with a doll, and a family deported from the ghetto. An analysis of his painting in the context of the Holocaust experience depicted in the said motifs enables us to describe the process of the sublimation of Bogen's Holocaust trauma through metamorphoses of form, meaning, and colour.

Keywords: Holocaust art, Alexander Bogen, colourism, metamorphosis, revival, Holocaust iconography, painting

\begin{abstract}
Abstrakt
Według prowadzonych przeze mnie badań, w latach 1946-1950 było czynnych około 40 plastyków - Ocalonych z Zagłady. Jednym z nich był wilnianin - Aleksander Bogen (1916-2010). Partyzant, uczestnik akcji ratowania ludzi z getta. Lata 1947-1951 spędził w Łodzi. Emigrował do Izraela, gdzie uważany jest za jednego z wybitniejszych kolorystów. Chociaż nie było jego zamiarem podejmowanie tematyki Zagłady, w jego twórczości pojawiają się

\footnotetext{
Doktor Magdalena Tarnowska jest historykiem sztuki, kustoszem dyplomowanym. W kręgu jej zainteresowań naukowych znajdują się: kultura i sztuka Żydów połowy XIX i XX wieku w kontekście sztuki polskiej i europejskiej, w tym sztuka Holokaustu, podróże artystyczne do Palestyny, badania proweniencji dzieł sztuki. Członkini Zespołu ekspertów ds. badań proweniencyjnych w muzeach polskich w zakresie mienia pożydowskiego, MKiDN (2009-2011), jury Ogólnopolskiego konkursu wiedzy o historii i kulturze Żydów polskich Fundacji Shalom. E-mail:m.tarnowska@uksw.edu.pl.
} 
motywy stanowiące jej symboliczne odwzorowanie: grupa partyzantów, dziewczynka z lalką, rodzina deportowana z getta podczas jego likwidacji. Analiza jego twórczości w kontekście doświadczeń Holokaustu obrazowanych poprzez te motywy pozwala opisać proces ich sublimacji poprzez metamorfozy formy, barwy i znaczeń.

Słowa kluczowe: sztuka Holokaustu, Aleksander Bogen, koloryzm, metamorfozy, odrodzenie, ikonografia Zagłady, malarstwo

$P^{\prime}$ rzed wybuchem II wojny światowej diaspora żydowska w Polsce należała do największych na świecie. Licząca około 3,5 mln osób, zróżnicowana światopoglądowo, wyznaniowo i społecznie współtworzyła wielokulturowy pejzaż kraju. Do najważniejszych ośrodków należały Warszawa - stanowiąca centrum kulturowe o zasięgu międzynarodowym, Lwów, Kraków, Łódź i Wilno.

W dwudziestoleciu międzywojennym działało około 600 plastyków pochodzenia żydowskiego $^{2}$. Środowisko to tworzyli przedstawiciele starszego i średniego pokolenia (urodzeni na przełomie XIX i XX wieku), o ugruntowanej pozycji zawodowej. Ich pracownie pełniły często funkcję salonów artystycznych, w których spotykała się inteligencja - literaci, ludzie teatru i świata muzycznego, a także młodzi adepci sztuki - rozpoczynający karierę lub studiujący w miejscowych i zagranicznych uczelniach.

W większości byli aktywni w dwóch obszarach kulturowych - polskim i żydowskim, co przejawiało się przede wszystkim udziałem w wystawach, stowarzyszeniach i grupach artystycznych. Uczestniczyli w ekspozycjach organizowanych przez Związek Zawodowy Polskich Artystów Plastyków (ZZPAP, przemianowany na ZPAP), Instytut Propagandy

\footnotetext{
2 Kwestia określenia tożsamości narodowej Żydów Polski międzywojennej jest problemem złożonym, ponieważ ta grupa miała jedynie status mniejszości wyznaniowej. W celu opisania zjawisk dotyczących ówczesnej sztuki żydowskiej przyjmuje się kryterium indywidualnego poczucia tożsamości przejawiającego się uczestnictwem w życiu artystycznym - polskim, żydowskim lub w obydwu. W pierwszych latach powojennych problem tożsamości stał się bardziej skomplikowany ze względu na tragiczne doświadczenia Żydów (m.in. traumę getta czy obozu koncentracyjnego, ukrywanie się po tzw. stronie aryjskiej, zagładę bliskich i całych społeczności czy poczucie zagrożenia ze strony współobywateli). Więcej zob.: B. Engelking, Na łące popiołów: ocaleni z Holocaustu, Warszawa 1993; taż, Zagłada i pamięć: doświadczenie Holocaustu i jego konsekwencje opisane na podstawie relacji autobiograficznych, Warszawa 1994; M. Melchior, Zagłada a tożsamość, Warszawa 2004.

Podana liczba na podstawie wyników badań nad żydowskim środowiskiem artystycznym w Polsce prowadzonych od lat osiemdziesiątych XX w. przez prof. dr hab. Jerzego Malinowskiego i grono historyków sztuki związanych z Żydowskim Instytutem Historycznym w Warszawie (ŻIH). Od lat dwutysięcznych kontynuowane są przez Polski Instytut Studiów nad Sztuką Świata w Warszawie. Wyniki badań publikowane są w serii wydawniczej PISnSŚ: Sztuka żydowska w Polsce i Europie Środkowo-Wschodniej, Studia i monografie, także w periodykach ww. instytucji. Badania nad historią, kulturą Żydów polskich prowadzą również: Polskie Towarzystwo Studiów Żydowskich (1996), Uniwersytet Jagielloński (Katedra Judaistyki 2000-2012, następnie Instytut Judaistyki), Instytut Sztuki PAN, Uniwersytet Wrocławski (Katedra Judaistyki, 2003), Centrum Badań nad Zagładą przy Instytucie Filozofii i Socjologii PAN (2003), Uniwersytet Łódzki (Centrum Badań Żydowskich przy Instytucie Historii, 2005, oraz Instytut Historii Sztuki). Przekrojowymi publikacjami na temat polsko-żydowskiego środowiska artystycznego są m.in.: I. Gadowska, Żydowscy malarze w Lodzi w latach 1880-1919, Warszawa 2010; D. Kacprzak, Kolekcje ziemi obiecanej: zbiory artystyczne łódzkiej burżuazji wielkoprzemysłowej w latach 1880-1939, Warszawa 2015; J. Malinowski, Malarstwo i rzeźba Żydów polskich w XIX i XX wieku, Warszawa 2000; tenże, Katalog dziet artystów polskich i żydowskich z Polski w muzeach Izraela, Warszawa 2018; Muzeum Żydowskiego Instytutu Historycznego. Zbiory artystyczne, Warszawa 1995; R. Piątkowska, Między Ziemiańska a Montparnasse'em, Warszawa 2004; Żydzi w Polsce. Obraz i stowo, red. M. Rostworowski, Warszawa 1993; N. Styrna, Zrzeszenie Żydowskich Artystów Malarzy i Rzeźbiarzy w Krakowie 1931-1939, Kraków 2009; M. Tarnowska, Artyści żydowscy w Warszawie 1939-1945, Warszawa 2015; M. Zientara, Krakowscy artyści i ich sztuka w latach 1939-1945, Kraków 2013.
} 
Sztuki (IPS), Towarzystwo Zachęty Sztuk Pięknych (TZSP), Towarzystwo Przyjaciół Sztuk Pięknych (TPSP) oraz przez Żydowskie Towarzystwo Krzewienia Sztuk Pięknych (ŻTKSP) założone w 1923 roku i Żydowskie Stowarzyszenie Artystów Plastyków (ŻSAP) działające od lat trzydziestych XX w. Tworzone przez nich dzieła, zarówno w warstwie formalnej, jak ikonograficznej, reprezentowały aktualne tendencje sztuki polskiej i europejskiej. Nieliczni - przeważnie przedstawiciele młodszego pokolenia - podejmowali tematy związane z problematyką tożsamości czy poszukiwaniem stylu narodowego. Wynikało to zazwyczaj z ich zaangażowania w ruchy polityczne bądź opowiadające się za rozwojem kultury jidysz w Diasporze lub syjonistyczne promujące ideę utworzenia własnego państwa i nowej sztuki opartej na dziedzictwie Bliskiego Wschodu.

Holokaust położył kres społeczności Żydów w Europie. Jej odrodzenie wydawało się niemal nierealne z powodu prawie całkowitego wyniszczenia populacji (ocalało zaledwie kilka procent) oraz jej dorobku duchowego i materialnego. Jednak Polska, na kilka powojennych lat, stała się ośrodkiem odbudowy życia żydowskiego. Było to możliwe dzięki akcji repatriacyjnej obywateli II Rzeczypospolitej z ZSRR. We wrześniu PKWN podpisało z rządami zachodnich republik ZSRR umowę o repatriacji obywateli polskich, dzięki której liczba Żydów wzrosła do 250 tysięcy w końcu 1946, zaś w 1948 roku na skutek migracji wynosiła już tylko 100 tysięcy $^{3}$. W listopadzie 1944 na wniosek Referatu do spraw Pomocy Ludności Żydowskiej został utworzony przy PKWN Centralny Komitet Żydów Polskich (CKŻP), który pełnił rolę politycznej reprezentacji wobec władz polskich oraz wobec organizacji żydowskich za granicą, a także zajmował się organizacją życia na terenie całego kraju4 . Od lutego 1945 siedziba Komitetu mieściła się w Warszawie przy ul. Siennej 60.

\footnotetext{
3 Umowa dotyczyła obywatelstwa polskiego sprzed 1 września 1939. Około 100 tysięcy ze 150 tys. przybyłych Żydów skierowano na Dolny Śląsk i Pomorze Zachodnie. W połowie lipca 1946 Ministerstwa Bezpieczeństwa Publicznego i MSZ wyraziły zgodę na emigrację Żydów organizowaną przez Koordynację Syjonistyczną Bricha (powstałą w lutym 1944). Większość emigrantów przekraczała granice na Dolnym Śląsku. Działalność Brichy ograniczono w lutym 1947. Do 1947 za jej pomocą emigrowało ok. 140 tys. osób, głównie do Palestyny. Na temat imigracji do Plestyny, od 1948 Izraela, w kontekście sytuacji społeczno-politycznej oraz przemian postaw społeczneństwa wobec Holokaustu i Ocalonych, zob.: T. Segev, Siódmy milion. Izrael - piętno Zagłady, thum. B. Gadomska, Warszawa 2012.

4 Struktura organizacyjna CKŻP odpowiadała podziałowi terytorialnemu Polski. W 1946 było 9 komitetów wojewódzkich i 7 okręgowych, zaś sam Komitet składał się z 19 wydziałów, w których pracowało łącznie 25 osób - przedstawicieli poszczególnych partii politycznych. Wydziały CKŻP: Sekretariat, Personalny, Organizacji i Kontroli, Ewidencji i Statystyki, Repatriacyjny, Finansowy, Opieki Społecznej, Opieki nad Dzieckiem, Szkolny, Młodzieżowy, Produktywizacji, Emigracyjny, Propagandy i Kultury, Centralna Biblioteka Żydowska, Centralna Komisja Historyczna, Prawny, Gospodarczy, Techniczno-Budowlany, Specjalny. Pierwszym przewodniczącym był Emil Sommerstein (1883-1957), prawnik, działacz syjonistyczny, społeczny we Lwowie, od 1946 Adolf (Abraham) Berman (1906-1978), działacz syjonistyczny, filozof, zaś od 1949 Hersz (Grzegorz) Smolar (1905-1993), literat, dziennikarz, działacz komunistyczny. CKŻP istniał do 1950, kiedy połączono go z Żydowskim Towarzystwem Kultury i utworzono Towarzystwo Społeczno-Kulturalne Żydów Polskich. Na temat CKŻP zob.: Zarys działalności CKŻP za okres od 1 stycznia do 30 czerwca 1946, Warszawa 1947; E. Hornowa, Powrót Żydów polskich z ZSRR oraz działalność opiekuńcza Centralnego Żydowskiego Komitetu Żydów w Polsce, „Biuletyn Żydowskiego Instytutu Historycznego", 1982, nr 1-2, s. 105-122; L. Olejnik, Polityka narodowościowa Polski w latach 1944-1960, Łódź 2003; T. Epsztein, Wstęp, w: Inwentarz Archiwum Wydzialu Statystyki i Ewidencji Centralnego Komitetu Żydów w Polsce 1945-1950, Warszawa 2019, s. 2-13.

Także seria wydawnicza ŻIH zatytułowana $Z$ dziejów Centralnego Komitetu Żydów w Polsce: A. Cała, Ochrona bezpieczeństwa fizycznego Żydów w Polsce powojennej. Komisje Specjalne przy Centralnym Komitecie Żydów $w$ Polsce, Warszawa 2014; A. Żbikowski, Sąd Społeczny przy CKŻP. Wojenne rozliczenia społeczności żydowskiej w Polsce, Warszawa 2014; A. Grabski, Centralny Komitet Żydów w Polsce (1944-1950). Historia polityczna, Warszawa 2015; P. Kendziorek, Program i praktyka produktywizacji Żydów polskich w działalności CKŻP, Warszawa 2016; H. Datner, Po Zagładzie Społeczna historia żydowskich domów dziecka, szkól, kót studentów w dokumentach Centralnego Komitetu Żydów w Polsce, Warszawa 2016; A. Żółkiewska, Zerwana przeszłość. Powojenne środowi-
} 
Podstawą finansów CKŻP były dotacje państwowe, składki oraz subwencje pochodzące głównie od amerykańskiej instytucji charytatywnej Joint [właśc. American Jewish Joint Distribution Commitee AJDC $]^{5}$.

Sytuacja repatriantów była bardzo trudna. Najczęściej byli pozbawieni jakichkolwiek dóbr materialnych, musieli także mierzyć się z tragedią utraty bliskich i dalszych krewnych, a często całych rodzin. Niemal wszyscy korzystali z pomocy CKŻP. Otrzymywali pomoc materialną i mieszkaniową, zatrudnienie. W gestii Komitetu leżały także: opieka nad sierotami i potrzebującymi, lecznictwo, szkolnictwo, kultura, sprawy emigracji i poszukiwanie krewnych, także rejestracja ocalonych przez Wydział Repatriacji przy współpracy z Państwowym Urzędem Repatriacji (PUR) ${ }^{6}$. Tylko w 1946 utworzono ponad 100 spółdzielni dających zatrudnienie około 43 tysiącom osób 7 . Pod auspicjami Komitetu funkcjonowały organizacje, m.in.: Towarzystwo Ochrony Zdrowia, Centrala Spółdzielni Wytwórczych „Solidarność”, Bank dla Produktywizacji Żydów ${ }^{8}$.

Należy przy tym zaznaczyć, że odbudowa życia żydowskiego w latach 1945-1949 była kontrolowana przez władze komunistyczne. Przy czym w pierwszym okresie obejmującym lata 1945-1947 rząd wspierał zarówno proces odrodzenia, jak i pewną autonomię polityczno-społeczną i kulturową Żydów, zaś w latach 1948-1949 za sprawą zmian politycznych stopniowo wycofywał wsparcie, aż do całkowitej likwidacji tej ,autonomii”"

Wraz z odbudową życia po wojnie z upadku podnosiła się też kultura. Jej rozwój wspierał i nadzorował Wydział Kultury i Propagandy (WKiP), utworzony wiosną 1945 r. w obrębie CKŻP. Jego celem było przede wszystkim: „Zaspokojenie potrzeb kulturalnych i oświatowych mas żydowskich przez zakładanie domów kultury, bibliotek, teatrów, organizowanie wszelkiego rodzaju kursów, szkół i wydawnictw"10.

Instytucją koncentrującą swoją działalność na środowisku artystycznym było Żydowskie Towarzystwo Krzewienia Sztuk Pięknych (ŻTKSP), utworzone na początku 1947 roku w Warszawie, przez Józefa Sandla - marszanda i historyka sztuki oraz znanego rzeźbiarza Natana Rapoporta ${ }^{11}$. Do zadań realizowanych przez Towarzystwo należały: zabezpieczanie

sko żydowskiej inteligencji twórczej. Pomoc materialna i organizacyjna ze strony CKŻP, Warszawa 2017; A.M. Rosner, Obraz społeczności ocalałych w Centralnej Kartotece Wydziału Ewidencji i Statystyki CKŻP, Warszawa 2018.

5 CKŻP tylko 1946 dysponował ponad 146 milionami. Zob.: Zarys działalności CKŻP za okres od 1 stycznia do 30 czerwca 1946, Warszawa 1947, s. 9 (od rządu otrzymano $32 \mathrm{mln}$ ).

6 Zob.: K. Kersten, Repatriacja ludności polskiej po II wojnie światowej, Wrocław-Warszawa-Kraków-Gdańsk 1974, s. 13; Zarys..., s. 7.

7 Zob.: M. Grynberg, Żydowska spółdzielczość pracy w Polsce w latach 1945-1949, Warszawa 1986.

8 Zob.: Zarys..., s. 4-5 i s. 11.

9 Więcej na ten temat, zob.: L. Olejnik, Polityka narodowościowa polski w latach 1944-1960, Łódź 2003; A. Rykała, Przemiany sytuacji społeczno-politycznej mniejszości żydowskiej w Polsce po drugiej wojnie światowej, Łódź 2007.

10 Zarys..., s. 6.

11 Józef Sandel (1894-1962) - od 1920 działał w środowisku drezdeńskiej awangardy, wydawał lewicowe pismo „Der Mob”, prowadził też salon Galerie Junge Kunst Joseph Sandel. Od 1936 w Warszawie zajmował się organizacją wystaw żydowskich. Drugą wojnę światową przeżył w ZSRR, w Samarkandzie. Do Warszawy wrócił w czerwcu 1946. Prezes ŻTKSP, po jego likwidacji w 1949 przeszedł wraz z Galerią Sztuki Żydowskiej do ŻIH, gdzie pracował do 1953. Publikował m.in. w: „Literarisze Bleter”, „Hajnt”, „Naszym Słowie”.

Natan (Naftali) Rapoport (1911-1987), absolwent warszawskiej ASP (1936). Debiutował w 1933 w ŻTKSP. Wystawiał także w IPS. Drugą wojnę światową spędził w ZSRR (Białystok, Mińsk, Ałma Ata, więziony w łagrze w Nowosybirsku, po zwolnieniu w Moskwie). Od 1946 w Warszawie. Autor Pomnika Bohaterów Getta, 1948. Od 1949 w Izraelu. Mieszkał i tworzył w kibucach: Jad Mordechai, Negba i Ramat Gan, gdzie znajduje się jego dom 
resztek dziedzictwa kulturowego w celu utworzenia Muzeum Sztuki Żydowskiej, udzielanie plastykom pomocy materialnej, lokalowej, zapewnienie im zatrudnienia, przydział farb, płócien czy innych potrzebnych materiałów, organizowanie wystaw, plenerów, wykładów, akcji promocyjnych w prasie i radiu ${ }^{12}$. Dzięki jego wysiłkom, środowisko, choć poniosło olbrzymie straty, dość szybko wznowiło swoją działalność.

Przeprowadzone przeze mnie badania wykazały, że latach 1946-1950 na terenie Polski tworzyło około 40 plastyków - Ocalonych z Zagłady - czynnych przed 1939 rokiem oraz niewielka liczba studentów (około 10 osób) ${ }^{13}$. Większość z nich osiedliła się w Łodzi stanowiącej wówczas centrum administracyjne i kulturowe w zastępstwie zburzonej Warszawy. W mieście odbywała się też większość wystaw sztuki, nie tylko o znaczeniu lokalnym, ale i krajowym. Do najbardziej aktywnych i znaczących członków łódzkich plastyków żydowskich należeli: malarze - Aleksander Bogen, Henryk Hechtkopf, Rafał Mandelzweig, Maurycy Bromberg, Sara Gliksman, Adam Muszka, rzeźbiarze i metaloplastycy - Sara Gorszajn, Chaim Hanft, Beniamin Pacanowski, Józef Fajngold ${ }^{14}$. W lutym 1947 r., w celu poprawy swojej sytuacji finansowej, założyli Spółdzielnię Artystyczno-Malarską „Sztuka”

i pracownia. Miał też atelier w Paryżu. Od 1959 w Nowym Jorku. Autor monumentów, m.in.: pomnik Mordechaja Anielewicza, 1951 w kibucu Jad Mordechai, Zwój Ognia, 1971 w Jerozolimie, pomnik Sześciu Milionów Ofiar Nazizmu, 1964 w Filadelfii.

12 Na temat ŻTKSP i żydowskiego środowiska artystycznego w Polsce zob.: M. Tarnowska, Żydowskie środowisko artystyczne w Warszawie w latach 1945-1949, „Pamiętnik Sztuk Pięknych. Sztuka Polska 1945-1970”, 2015, nr 9, s. 33-61; taż, Jewish Artistic Revival in Lower Silesia (Poland) 1945-1949: Art and Activity in the Light of Source Materials and Art Criticism, „Kwartalnik Historii Żydów”, 2020, nr 2, s. 425-450. W pierwszym artykule znajduje się bibliografia tematu.

13 Niewielka liczba zamieszkała także na Dolnym Śląsku, w Warszawie i Krakowie.

14 Henryk Hechtkopf (1910-2004), rysownik, grafik, malarz. Mieszkał w Warszawie. Uczeń malarzy Henryka Berlewiego i Władysława Weintrauba. W latach 1932-1936 brał udział w wystawach ŻTKSP w Warszawie. Drugą wojnę światową spędził w ZSRR. Od lutego 1946 do 1957 mieszkał w Łodzi. Działał w ŻTKSP, wystawiał też w ZZPAP, pracował w Łódzkiej Szkole Filmowej. Autor cyklu rysunków ukazujących ruiny getta warszawskiego. Od 1957 w Izraelu. Był znanym ilustratorem książek, pejzażystą, twórcą kompozycji symbolicznych i figuralnych na temat żydowskiej Diaspory.

Rafał Mandelzweig (Mendelzwajg, 1908-1956), malarz, grafik. Pochodził z Warszawy. Studiował w Brukseli i Paryżu. Od 1932 wystawiał w ŻTKSP, IPS, w Łodzi. W 1939 miał wystawę indywidualną w Radomiu. Drugą wojnę Światową spędził w Samarkandzie, gdzie tworzył i wystawiał. Brał udział w wystawie sztuki białoruskiej w Moskwie w 1940. Repatriowany w 1946, w 1947 mieszkał we Wrocławiu. Działał w ŻTKSP. W 1947 wyjechał do USA, stamtąd do Argentyny. Zmarł w Montevideo.

Maurycy (Mosze) Bromberg (1920-1989), grafik, malarz, rzeźbiarz, z Piotrkowa Trybunalskiego. Studiował w Monachium, ASP w Krakowie i we Lwowie, gdzie przebywał do czerwca 1941, potem w Samarkandzie. Po powrocie mieszkał w Łodzi. Wystawiał metaloplastyki o tematyce związanej z Zagładą i tradycją żydowską w ŻTKSP, ZZPAP. Po 1950 r. emigrował z Polski, zamieszkał w Kanadzie.

Sara Gliksman-Fajtlowicz (1909-2005), malarka. Mieszkała w Łodzi do 1957. Uczyła się malarstwa w szkołach prywatnych w Łodzi i Warszawie. Od 1934-1939 była związana z ZZPAP. Ocalona z getta łódzkiego. Wystawiała z ŻTKSP i ZPAP. Ceniona kolorystka. Od 1957 w Izraelu, w Tel Awiwie. Kontynuowała karierę artystyczną do lat siedemdziesiątych XX w.

Adam (Aron) Muszka (1914-2005), malarz, rzeźbiarz. Uczył się w Miejskiej Szkole Sztuk Zdobniczych w Warszawie. Przed 1939 wystawiał w ŻTKSP. Wojnę spędził w ZSRR, w Uzbekistanie. Od II 1946 mieszkał w Łodzi. Działał w ŻTKSP, wystawiał też w ZPAP. W 1967 emigrował do Paryża. Malował sceny z życia przedwojennej Diaspory.

Sara Gorszajn (?-?), rzeźbiarka. Debiutowała w latach trzydziestych XX w. w wystawach ŻTKSP. Po wojnie mieszkała w Łodzi, wystawiała w ZZPAP i ŻTKSP. Była cenioną autorką rzeźb figuralnych, portretów. Prawdopodobnie około 1950 wyjechała z Polski.

Beniamin Pacanowski (1901-1977), rzeźbiarz, metaloplastyk, scenograf. Przed 1939 wystawiał w ŻTKSP. Po drugiej wojnie światowej mieszkał w Łodzi. Wystawiał w ZTKSP i ZZPAP. Tworzył scenografie dla Państwowego Teatru Żydowskiego im. E.R. Kamińskiej w Łodzi. 
z siedzibą w lokalu przy ul. Piotrkowskiej $42^{15}$. Czasem szczególnej aktywności na niwie kulturalnej był rok 1948 - V rocznica powstania w getcie warszawskim. Organizowano uroczyste akademie, przedstawienia teatralne, wydarzenia artystyczne, w tym dwie duże wystawy zbiorowe artystów żydowskich - w 1948 r. w Łodzi i w 1949 r. we Wrocławiu ${ }^{16}$. Przy czym należy mieć na uwadze, że plastycy żydowscy należeli także do ZPAP i brali udział w jego wystawach.

Proces odbudowy życia żydowskiego przerwało nadejście czasów stalinowskich. Na przełomie 1949 i 1950 roku wszystkie organizacje, stowarzyszenia, wydawnictwa, prasa, niemal wszystkie instytucje poza Żydowskim Instytutem Historycznym w Warszawie, zostały zlikwidowane. W tym okresie większość plastyków emigrowała, ci, którzy pozostali, opuścili Polskę po 1968 roku.

Holokaust zniszczył nie tylko społeczność żydowską Europy i jej dziedzictwo, pozostawił także niezatarty ślad w psychice tych, którzy przetrwali i wywarł wpływ na życie następnych pokoleń. Stał się także elementem narracji historycznej, literackiej i artystycznej kultury europejskiej, a nawet światowej.

W obszarze sztuk pięknych trauma Zagłady obrazowana jest poprzez użycie różnorodnych środków wyrazu. Ich dobór zależny jest przede wszystkim od postawy przyjmowanej przez danego twórcę wobec osobistych przeżyć oraz od tego, w jaki sposób pojmuje on swoją rolę w procesie przekształcania ich w jakości uniwersalne - czytelne dla odbiorców nieposiadających doświadczeń tego rodzaju.

Dokonując wyboru najbardziej reprezentatywnego malarza z grona łódzkich artystów Ocalonych - wymienionych powyżej, przyjęłam następujące kryteria: doświadczenie Holokaustu i jego obecność w twórczości, odpowiednia ilość materiału pozwalająca na dokonanie analizy procesu jego przemiany oraz wiodąca rola koloru jako środka jego wizualizacji. Tylko dwoje spośród nich było bezpośrednimi świadkami Zagłady - Sara Gliksman i Aleksander Bogen. Pozostali przeżyli lata wojny na terenie ZSRR. Wszystkie trzy warunki spełnia jedynie twórczość Bogena. Utalentowana kolorystka - Sara Gliksman przebywająca w getcie łódzkim przez cały okres okupacji niemieckiej, aż do wyzwolenia miasta 19 stycznia 1945 roku, konsekwentnie nie podejmowała w swoim malarstwie tematyki przeżyć wojennych ${ }^{17}$.

\footnotetext{
Józef Fajngold (1910-1998), rzeźbiarz, metaloplastyk. Pochodził z Warszawy, absolwent ASP (1932). Wystawiał w ŻTKSP, SŻAPwP, TZSP. Podczas drugiej wojny światowej przebywał w ZSRR, brał udział w wystawie Dekada sztuki białoruskiej w Mińsku. W latach 1942-1944 należał do Związku Plastyków Radzieckich. Od 1944 w Wojsku Polskim. Od 1946 mieszkał w Łodzi, potem w Warszawie. Wystawiał w ZPAP.

15 Spółdzielnia powstała we współpracy z Wojewódzkim Komisarzem ds. Produktywizacji Ludności Żydowskiej. W jej skład weszli: prof. Perec Willenberg (przewodniczący), B. Pacanowski, J. Fajngold, M. (?) Bekerman, M. Lubliński, J. [Nachum] Edelman, Tomasz Gleb, S. Gorszajn, S. Gliksman, Jecheskiel Mucznik, A. Muszka, Karol Piasecki, Izaak Rajzman, Dorota Szenfeld, zob.: „Opinia”, 1947, nr 11, s. 9.

16 T. Grygiel, Wystawa zbiorowa Grupy Artystów w Żydów w Łodzi, „Nasze Słowo”, 1948, nr 2, s. 6. Wystawa w ramach miesiąca kultury żydowskiej. 157 prac. Uczestnicy: A. Bogen, S. Gliksman, H. Hechtkopf, Z. Walkman (z Palestyny), D. Szenfeld, M. Bromberg, H. Olszewska, J. Sobel, R. Gryner (z Brazylii), E. Kaganowski, K. Piasecki, A. Muszka, T. Estelle, J. Fajngold, Sz. Fogelman, S. Gorszeni, B. Pacanowski, I. Rajzman, B. Ołomucki, J. Mucznik, M. Lubliński, N. Gutman, M. Bekerman; S. Gelbart, Zbiorowa wystawa plastyków żydowskich, „Mosty - Nasze Słowo", 1949, nr 41, s. 7.

17 Referat poświęcony życiu i twórczości artystki w latach 1939-1957 autorka niniejszego tekstu prezentowała podczas międzynarodowej konferencji online Kobieta żydowska. Nowe badania i perspektywy badawcze, Kraków 26-28.04.2021.
} 
Alexander Bogen (właśc. Katzenbogen, 1916, Tartu (Dorpat) w Estonii - 2010, Tel Awiw) jest postacią szczególną ze względu na niezwykły talent, barwną osobowość oraz chlubną przeszłość wojenną. Bojownik, malarz, rzeźbiarz, pedagog, społecznik, właściwie od momentu imigracji do Izraela w 1951 roku uważany jest za jedną z ważniejszych postaci tamtejszego świata sztuki ${ }^{18}$. Przez ponad sześćdziesiąt lat kariery cieszył się międzynarodowym uznaniem krytyków i koneserów sztuki. Miał ponad 30 wystaw indywidualnych na całym świecie ${ }^{19}$.

Dzieciństwo i młodość spędził w należącym wówczas do Polski Wilnie. Jego rodzice byli lekarzami sympatyzującymi z lewicą i zwolennikami rozwoju życia w Diasporze. Miasto było jednym z ważniejszych ośrodków kultury polsko-żydowskiej. Działały tu m.in.: Wileńskie Towarzystwo Artystów Plastyków (od 1921), Związek Żydowskich Artystów Plastyków, Żydowskie Towarzystwa Popierania Sztuki (1924), słynny w całym świecie Żydowski Instytut Naukowy IWO (Idisze Wiesenszaft Organizacje, 1925). Organizowano liczne wystawy, odczyty, kursy artystyczne. Bogen po ukończeniu gimnazjum, w 1936 r. wstąpił na Wydział Sztuk Pięknych Uniwersytetu Stefana Batorego, gdzie studiował rzeźbę i malarstwo ${ }^{20}$. Należał do najmłodszego pokolenia wileńskich artystów żydowskich (liczącego około 30 osób), ukształtowanego przede wszystkim przez profesorów uczelni - kolorystów, jak Ferdynand Ruszczyc, Tymon Niesiołowski czy Ludomir Ślendziński ${ }^{21}$. Wpływ na młodego malarza wywarły też dokonania grupy „Jung Wilne” i przedstawicieli awangardy związanych z Wilnem, jak Michel Kikoine (1892-1968), Lasar Segall (1891-1967) oraz twórczość

18 Pełnił m.in. funkcje prezesa Związku Artystów Plastyków Izraela, w latach 1952-1980 dyrektora Wydziału Sztuki w Miejskiej Wyższej Szkole Zawodowej Wizo-Zarfat w Tel Awiwie. Był także wykładowcą Uniwersytetu Hebrajskiego w Jerozolimie. Był wielokrotnie nagradzany, m.in.: Polska, 1951 - Nagroda Państwowa; Izrael 1961, Nagroda Histadrut; 1962, Nagroda Ministra Edukacji i Kultury; 1982, Nagroda Negew; 1995, Nagroda Szaloma Alejchema.

19 Życie i działalność artysty są jednym z elementów moich badań nad żydowskim środowiskiem artystycznym w Polsce w latach 1945-1951.

Podstawową pozycją na temat malarza obejmującą okres jego życia w Izraelu w 1. 1951-2005 jest album: A. Bogen, Z. Amishai-Msisels, Alexander Bogen, Israel 2005. Zawiera trzy eseje na temat jego twórczości oraz jego wypowiedź na temat procesu tworzenia, ogólnikową biografię, reprodukcje prac. Materiały z tego opracowania dostępne są częściowo na stronie internetowej Alexander Bogen Foundation: Alexander Bogen http://alexanderbogen.com/ (dostęp 20.05.2020).

Losy i działalność artysty w czasie pobytu w Łodzi 1947-1951 są w obcojęzycznej literaturze przedmiotu nieznane. Więcej na ten temat zob.: M. Tarnowska, Żydowscy artyści...

Na temat życia i twórczości Bogena w latach 1941-1945 zob.:

Bogen (Katzenbogen) A. (Shura), The Onset of the Partisan Units in the Forest of Naroch, http://www.eilatgordinlevitan.com/vilna/vilna_pages/vilna_stories_alexander_bogen.htm (dostęp 20.05.2020); Alexander Bogen Collection at the United States Holocaust Memorial Museum in Washington D.C., https://collections.ushmm.org/ search?q=Bogen\%2C\%20Alexander.\&search_field=Subject (dostęp 14.10.2020); The Pen and the Sword, https:// www.yadvashem.org/yv/en/exhibitions/bogen/index.asp (dostęp 14.10. 2020); J. Merav, M. Sternin, Interview with Alexander Bogen, Survivor and Artist, https://www.yadvashem.org/articles/interviews/alexander-bogen.html (dostęp 20.05.2020).

20 Na temat środowiska artystycznego Wilna zob.: J. Malinowski, Malarstwo i rzeźba Żydów polskich w XIX $i$ XX wieku, Warszawa 2000, s. 381-397.

${ }^{21}$ Ferdynand Ruszczyc (1870-1936), malarz, grafik scenograf. Od 1904 profesor Szkoły Sztuk Pięknych w Warszawie, 1907-1908 Akademii Sztuk Pięknych w Krakowie. Od 1919 profesor Wydziału Sztuk Pięknych USB.

Tymon Niesiołowski (1882-1965), malarz, grafik. Członek Stow. Formistów, Stow. AP „Rytm”. Do 1926 mieszkał w Zakopanem. Od 1928 wykładowca USB. Od 1945 profesor UMK w Toruniu.

Ludomir Ślendziński (1889-1980) malarz i rzeźbiarz, członek Stow. AP „Rytm”. Od 1928 prof. WSz USB, od 1945 Politechniki Krakowskiej. 
Picassa i Matisse'a. Zadebiutował w 1935 r. na ekspozycji zbiorowej w IWO ${ }^{22}$. W 1937 r. uczestniczył w Wystawie Młodych Żydowskich Artystów Plastyków ${ }^{23}$.

Już podczas wojny - 6 maja 1940 r. - poślubił w Święcianach Rachelę Szachor (1914-1998) ${ }^{24}$. Edukację Bogena przerwało wkroczenie wojsk niemieckich do miasta 22 czerwca 1941 r. Po nieudanej próbie przedostania się na Wschód, do Mińska, znalazł się wraz z rodziną w getcie w Święcianach. Po ucieczce z niego, przyłączył się do oddziałów białoruskiej partyzantki walczących w lasach Naroczy, pod dowództwem pułkownika Markowa. Pod pseudonimem Szura dowodził plutonem żydowskich bojowców Nekama (hebr. zemsta). Brał udział w wielu bitwach i akcjach dywersyjnych, m.in. w przerzuceniu z getta wileńskiego do lasu stu pięćdziesięciu członków tamtejszej konspiracyjnej Zjednoczonej Organizacji Partyzanckiej (jid. Farejnikte Partizaner Organizacje, FPO), w czasie prowadzonej tam od 11 września 1943 r. akcji likwidacyjnej. Wśród nich byli słynni poeci: Abe Kowner (1918-1987) - przywódca FPO i Abraham Sutzkever (1913-2010, od 1947 Tel Awiw), szkolny kolega Aleksandra. Ocalił również żonę i jej matkę.

Poza udziałem w konspiracji pracował nad stworzeniem rysunkowej dokumentacji życia partyzantów, a także losów więźniów getta. Podobnie jak wielu innym twórcom czasów Holokaustu przyświecała mu chęć zachowania pamięci o tragedii: „Kiedy pytałem siebie, po co to wszystko rysuję - mówił - kiedy niemal bez ustanku walczę, odkryłem, że kieruje mną instynkt fizycznego przetrwania. [...] Innym motywem było przekazanie wolnemu światu informacji o zbrodniach niemieckich"25.

Bogen wrócił do wyzwolonego Wilna w 1944 r. i podjął przerwane studia artystyczne. Ukończył je w 1947 r. i w tym samym roku osiedlił się wraz z rodziną w Łodzi ${ }^{26}$. Trzy lata spędzone w mieście były dla niego czasem pomyślności. Nawet po wielu latach wspominał je dobrze: „W Łodzi czułem się wspaniale. Byłem znanym artystą i otrzymywałem dużo zamówień rządowych. Mieszkałem w pięknym mieszkaniu, miałem dużą pracownię, byłem całkowicie bezpieczny"27. Po przyjeździe wszedł w skład ŻTKSP. Korzystał też z udzielnej przez CKŻP pomocy materialneje ${ }^{28}$. Współpracował z Adamem Muszką i Józefem Sandlem przy gromadzeniu dzieł artystów żydowskich. Podjął również pracę dydaktyczną w Pań-

22 „Jung Wilne”, grupa literacko-artystyczna, powstała w 1929 roku na wzór łódzkiej Jung Jidysz i warszawskiej Chaliastre, przeciwna ideom syjonistycznym, opowiadająca się za kultywowaniem kultury żydowskiej w Diasporze.

23 J. Malinowski, Malarstwo i rzeźba Żydów..., s. 393, 394.

24 Miasto na terytorium Litwy położone około $60 \mathrm{~km}$ od Wilna. Stamtąd pochodziła rodzina żony artysty. Archiwum Fundacji Aleksandra Bogena (AFB), Odpis skrócony aktu małżeństwa, wydany przez Państwowy Urząd Stanu Cywilnego w Łodzi, 22 listopada 1949.

25 A. Ćwiakowska, Spacer z Aleksandrem Bogenem, „Nowiny Kurier”, Tel Awiw, 1984, z 28 XII, s. 3.

26 Jak wskazują wyniki prowadzonych przeze mnie badań nad środowiskiem artystów żydowskich w latach 1945 -1956, Aleksander Bogen pełnił w nim niezwykle istotną rolę jako pedagog i malarz, animator kultury i krytyk artystyczny wyznaczający cele ideowe sztuki w nowej sytuacji geopolitycznej. Ten okres jego życia (z wyłączeniem malarstwa) opisałam częściowo w dwóch artykułach opublikowanych w języku polskim, zob.: M. Tarnowska, Aleksander Bogen (1916-2010). Przemiany postawy w świetle twórczości i krytyki artystycznej z lat 1945-1951, w: Oblicza utopii, obłudy i zakłamania 2, red. W. Łysiak, Poznań 2014, s. 107-118; taż, Żydowskie środowisko artystyczne w Warszawie w latach 1945-1949, „Pamiętnik Sztuk Pięknych. Sztuka Polska 1945-1970”, 2015, nr 9, s. 33-61.

27 J. Merav, M. Sternin, Interview with Alexander Bogen, Survivor and Artist, https://www.yadvashem.org/articles/interviews/alexander-bogen.html (dostęp 20.05.2020).

28 Archiwum ŻIH, ŻTKSP nr 361/II, podanie A. Bogena do Komisji Opieki Społecznej CKŻP z X 1947. 
stwowej Wyższej Szkole Sztuk Plastycznych (PWSSP) ${ }^{29}$. Brał udział w wystawach ZPAP i ŻTKSP, w 1949 roku miał wystawę indywidualną w łódzkim Ośrodku Propagandy Sztuki. Sale wystawowe dzielił z retrospektywą Janiny Muszkietowej (1903-1956) ${ }^{30}$. W 1951 roku emigrował wraz z rodziną do Izraela.

Dzieła Bogena, zachwycające umiejętnością przełożenia przejawów życia w feerię barw i syntetyczną formę, znajdują się w muzeach i kolekcjach prywatnych w Europie, obu Amerykach, Azji. W Polsce w Muzeum UMK w Toruniu, Muzeum Historii Żydów Polskich „Polin” w Warszawie. Rysunki wojenne w Holocaust Memorial Museum w Waszyngtonie, Yad Vashem Institute i Ghetto Fighters House w Izraelu. Jednak większość jego spuścizny obejmującej, oprócz prace plastycznych, także archiwalia, materiały prasowe, korespondencję i fotografie, znajduje się w posiadaniu Fundacji Aleksandra Bogena (The Alexander Bogen Foundation) w Tel Awiwie. Jej zbiory, z którymi zapoznałam się w 2020 roku na zaproszenie wnuczki i spadkobierczyni malarza pani Tali Bogen, pozwoliły mi znacząco uzupełnić zgromadzony dotąd materiał o nowe, nieznane mi wcześniej prace oraz informacje ${ }^{31}$.

Bogen był artystą wszechstronnym. Tworzył obrazy olejne, akwarele i gwasze, rysunki, grafiki, rzeźby, murale, projektował scenografię teatralną, ilustrował literaturę. Ukształtowany w szkole wileńskich kolorystów, przez całe życie poszukiwał barw, które w najdoskonalszy sposób oddawałyby jego zachwyt nad wciąż odradzającą się naturą i człowiekiem. Jego niezwykła wrażliwość na barwę pozwalała mu doświadczać związku pomiędzy nią a światem dźwięków. Sam podkreślał wielokrotnie tę fascynację: „Kiedy maluję akwarelami akrylami, gwaszem czy pastelami, potrafię odnaleźć właściwy dźwięk muzyczny barw i ich cudowną przejrzystość już za pierwszym uderzeniem pędzla"32.

Jego sztuka ewoluowała od realistycznych, ekspresyjnych przedstawień walki partyzanckiej i scen z likwidacji getta, poprzez syntezę form ku abstrakcji. Chociaż w jego dorobku przeważają pogodne pejzaże, sceny figuralne oraz kompozycje budowane wyłącznie kolorami odwołujące się przeważnie do bliskowschodnich krajobrazów, pojawiają się w nim motywy odnoszące się do traumy Holokaustu - niekiedy jako odrębne obrazy, niekiedy jako elementy mające za zadanie zakłócić idylliczny obraz świata.

W sztuce tworzonej przez artystów - Ocalonych można wyróżnić kilka postaw wobec traumy Holokaustu. Trzeba przy tym podkreślić, że są one wynikiem indywidualnej, niezwykle złożonej reakcji psychofizycznej na skrajne doświadczenia z czasów wojny.

Pierwszą z nich jest reakcja całkowitego wyparcia wspomnień, a tym samym zaniechanie - jak w przypadku wspomnianej już Sary Gliksman - tworzenia związanych z nimi przedstawień. Druga - przeciwstawna - to niejako trwanie w tamtej, przerażającej rzeczywistości. Jej skutkiem jest najczęściej odczuwanie konieczności ich obrazowania w celu zachowania dokumentów zbrodni nazistowskich, a także ku przestrodze dla potomnych. Taką drogę twórczą wybrali między innymi: Halina Ołomucka (Olomucki, ocalona z getta

\footnotetext{
29 ASP im. W. Strzemińskiego, wiosną 1945 przemianowana na - PWSSP.

30 Archiwum ŻIH, ŻTKSP nr 361/I, Korespondencja z 13 XI 1948 w sprawie wystawy Bogena w Łodzi; H., Zbiorowa wystawa plastyków żydowskich, „Mosty”, 1949, nr 41, s. 7; S. Gelbart, Wystawa obrazów J. Muszkietowej i Al. Bogena, ,Mosty”, 1948, nr 32, s. 3.

31 Pobyt w Izraelu zrealizowałam w ramach Erasmus+ KA 107. Umowa UKSW/BIU w Ramat Gam.

32 A. Bogen, Z. Amishai-Maiseles, Alexander..., s. 216.
} 
warszawskiego), David Olère - więzień KL Auschwitz-Birkenau ${ }^{33}$. Jak zauważa znana badaczka sztuki Holokaustu Ziva Amishai-Maisels - cechą charakterystyczną sztuki tego rodzaju jest ekspresja i realistyczne, niekiedy przerysowane formy ${ }^{34}$. Trzecią postawę można określić jako ambiwalentną. Jej cechą jest proces przemiany rozpoczynający się od świadomego dystansowania się od traumy Zagłady, poprzez powracanie do nich po upływie pewnego czasu przy jednoczesnej ich sublimacji, co zazwyczaj przejawia się w przekształcaniu ich w formy symboliczne i abstrakcyjne. Postawa Aleksandra Bogena wobec Holokaustu bliska jest tej ostatniej.

Początek jego kariery przypadł na ostatnie lata poprzedzające wybuch drugiej wojny światowej. Pomimo niewątpliwego talentu, młody artysta nie zdołał w pełni rozwinąć umiejętności warsztatowych ani określić swoich dążeń czy kierunków rozwoju. Ze względu na te okoliczności za pierwszy etap jego twórczości należy uznać prace powstające w latach 1939-1951 ${ }^{35}$. Przyjęcie takiego założenia umożliwia prześledzenie procesu transformacji jego doświadczeń okupacyjnych i jego odbicia w metamorfozach motywów, form i kolorów w dziełach powstających w różnych etapach życia malarza.

Będąc bezpośrednim świadkiem zagłady getta wieleńskiego i uczestnikiem walk partyzanckich, stworzył kilka rysunkowych przedstawień, do których wracał w ciągu długich lat aktywności zawodowej. Sięgał po nie pod wpływem aktualnych, głęboko go poruszających wydarzeń, m.in. głośnych procesów zbrodniarzy wojennych Adolfa Echmanna (1961-1962), Klausa Barbiego (1987) czy Iwana Demianiuka (1986-1988, 1993, 2008-2011).

Prace pochodzące $\mathrm{z}$ lat wojny oddają w pełni ich grozę. Cykl rysunkowy zatytułowany Partyzanci cechują ekspresyjne zwielokrotnione linie obrazujące emocje towarzyszące bojownikom. W jego graficznej wersji, dla oddania dramatyzmu walki z wrogiem, Bogen wykorzystał napięcie pomiędzy geometrycznymi plamami bieli, szarości i czerni a plątaniną wyrazistych linii. Po powrocie do rodzinnego miasta poświęcił się dokumentowaniu zniszczeń dzielnicy żydowskiej, tworząc kolejny cykl graficzny - Ruiny getta wileńskiego. Zastosował w nim zbliżone do poprzednich środki wyrazu w celu ukazania skali destrukcji tkanki miejskiej oraz oddania dojmującego uczucia pustki po pomordowanych. Podobne emocje budzą olejne widoki zburzonych domów i ulic getta. Malowane niewielkimi, falistymi plamami barwnymi, nakładanymi jedna przy drugiej, wywołują wrażenie niepokoju i smutku. Ich kolorystyka utrzymana w ciemnej tonacji brązów, chłodnych zieleni, szarości i złamanego błękitu potęguje jeszcze ten nastrój. Obrazy te przywodzą na myśl twórczość

\footnotetext{
33 Halina Ołomucka (Olomucki, z d. Olszewska, 1921-2007), malarka. Urodzona w Warszawie. Podczas wojny w getcie warszawskim. Po jego likwidacji ukrywała się w bunkrze. W maju 1943 znalazła się w transporcie do KL Majdanek. Więźniarka KL Auschwitz, KL Ravensbrück. Po wyzwoleniu osiadła w Łodzi, ukończyła tamtejszą PWSSP. W 1957 emigrowała do Paryża, stamtąd w 1972 do Izraela. Mieszkała w Holonie i Aszkelonie (tam zmarła). W czasie wojny i po jej zakończeniu tworzyła rysunki ukazujące tragiczny los więźniów getta i obozów koncentracyjnych oraz uwieczniała ich wizerunki.

David Olère (1902-1985), malarz, grafik. Pochodził z Warszawy. Od lat dwudziestych XX w. mieszkał w Paryżu, związany z École de Paris. W 1943 aresztowany przez policję francuską został wywieziony do KL Auschwitz. Przez cały okres pobytu w obozie pracował w Sonderkommando. Wyzwolony 19.02.1945, poświęcił się upamiętnieniu w swoich pracach przeżyć obozowych.

34 Więcej na ten temat zob.: Z. Amishai-Maisels, The Influence of the Holocaust on the Visual Arts, Oxford 1993.

35 Krytycy izraelscy w odniesieniu do twórczości Bogena wyróżniają trzy fazy rozwojowe, zaczynając od czasu jego osiedlenia się w Izraelu. Dorobek z lat 1939-1944 kwalifikują do sztuki Holokaustu.
} 
innego wilnianina Rafaela (Rafała) Chwolesa - Ocalonego, który poświęcił się dokumentowaniu zniszczeń rodzinnego miasta ${ }^{36}$.

Przełom w twórczości Bogena nastąpił po przybyciu do Izraela. Jak sam to określił w wywiadzie dla „Nowiny Kurier” z 1984 r.: „Jestem artystą, że użyję tego określenia, rozbitym na połowę, wyszedłem z piekła ciemności na światło słońca. Urodziłem się po raz drugi tutaj, w Izraelu. Oddycham jego światłem, słońcem, powietrzem. Mówią o mnie, że jestem kolorystą. Tak. Bo ja wszystkie te moje pieśni śpiewam kolorami”37.

Jego malarstwo z pierwszych piętnastu lat życia w Izraelu cechuje fascynacja Orientem jego światłem, intensywnymi barwami, przestrzenią pustyni, odmiennością kulturową. Tworzył wówczas pejzaże z Jaffy i Safed, gdzie miał dom letni, wizerunki kobiet arabskich $\mathrm{w}$ tradycyjnych strojach, sceny rodzajowe. Kompozycje budował dużymi plamami barwnymi określonymi mocnym, ciemnym konturem. Stosował jasne, czyste i nasycone barwy. W twórczości z lat sześćdziesiątych i siedemdziesiątych XX w. uwidacznia się dążenie do wyrażenia - poprzez formy abstrakcyjne i świetlistą kolorystykę - wartości duchowych, energii natury i radości istnienia. W ostatniej- mistrzowskiej fazie życia, począwszy od lat osiemdziesiątych XX w. do około 2008 roku, poświęcił się tworzeniu wielkich kompozycji, abstrakcyjnych i ekspresyjnych zarazem, o znaczeniu symbolicznym i uniwersalnym - swego rodzaju manifestów odnoszących się do Holokaustu rozumianego jako ciągłe zagrożenie utraty życia na ziemi spowodowane działalnością człowieka.

Bogen ukończył studia w 1947 roku pracą dyplomową Ostatnia rodzina w getcie, która, jak powiedział w przywołanym już wspomnieniu z 1984, miała być jego „symbolicznym zakończeniem rozrachunku z przeszłością" ${ }^{38}$. Jednak tak się nie stało. Nie zdołał uwolnić się od nękających go wspomnień. Do najbardziej znaczących motywów stanowiących ich odbicie, należą: portret grupowy partyzantów żydowskich, dziewczynka z lalką, rodzina deportowana z getta - starzec i kobieta z jednym lub dwojgiem dzieci. Dwa ostatnie są zapisem tragicznych scen rozgrywających się podczas likwidacji getta wileńskiego przeprowadzonej przez Niemców w dniach 23-24 września 1943 r.

Najwcześniejsza, rysunkowa wersja Partyzantów z 1943 r. to rodzaj kwintesencji woli walki zawartej w wizerunkach towarzyszy broni. Jej kolejne wersje są znakomitym przykładem przekształcenia dramatyzmu walki na śmierć i życie oraz towarzyszącej jej woli przetrwania w manifest polityczny i symboliczny zarazem - reprezentację bohaterstwa i wiary w siłę życia zdolnych pokonać zniszczenie. Pierwsza olejna wersja pochodząca z 1946 r. malowana jest w wąskiej gamie brązów, zieleni i czerni (il. 1). Postacie żołnierzy są stłoczone, zajmują całą powierzchnię obrazu. Zastosowanie tych środków daje efekt opresji, „braku powietrza”. W kompozycjach z lat siedemdziesiątych i osiemdziesiątych XX w. zaszły zmiany formalne obrazujące proces sublimacji doświadczeń wojennych malarza.

\footnotetext{
36 Rafael (Rafał) Chwoles (1913-2002), malarz, związany z Wilnem. Należał do grupy literacko-artystycznej Jung Wilne, działającej w latach 1929-1939. Debiutował w 1933 na Wystawie Młodych Malarzy w IWO. W 1940 pełnił rolę dyrektora Szkoły Sztuk Pięknych w Nowej Wilejce. Po ataku Niemiec na ZSRR wyjechał w głąb jego terytorium. Do Wilna wrócił latem 1944. Poświęcił się malowaniu obrazów ukazujących zniszczoną dzielnicę żydowską. W 1. 1959-1969 mieszkał w Warszawie. Emigrował do Paryża. Kontynuował karierę artystyczną. Tworzył głownie pejzaże, także wileńskie. W 2006 miał wystawę monograficzną w Toruniu. Więcej zob.: Wilno i caly świat w malarstwie Rafata Chwolesa, oprac. M. Supruniuk, M. Tarnowska, Toruń 2006, http://www.muzeum.umk.pl/pdf/ chwoles.pdf (dostęp10.10.2020).

37 A. Ćwiakowska, Spacer z..., s. 3.

38 Tamże.
} 


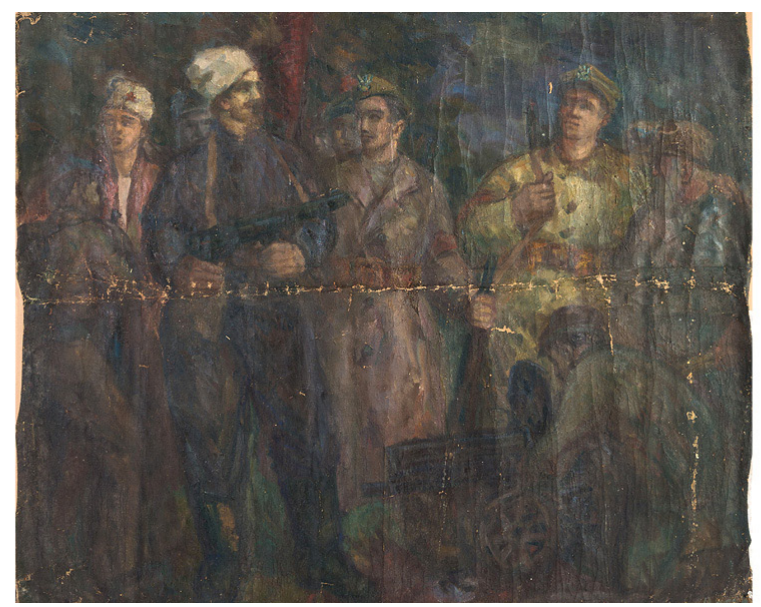

Il. 1. Aleksander Bogen, Partisans / Partyzanci, 1943, olej, płótno, $130 \times 160$ cm. Własność Alexander Bogen Foundation, Tel Awiw

Pojawia się w nich przestrzeń, jasne, wibrujące barwy z przewagą błękitów i bieli, nadające całości wrażenie pewnej ulotności. Zapewne upływ czasu spowodował wyciszenie emocji związanych z walką, pozwalając artyście na zyskanie dystansu do przeszłości. Ostatni obraz tej serii, z 1989 r., malowany w nasyconych i ciepłych barwach, jest już nieomal abstrakcją zbudowaną z plam barwnych obwiedzionych liniami lekko zaznaczonych czernią konturów określających sylwetki pięciu żydowskich bojowników (il. 2). Jednak nie tylko. Jest również sceną symboliczną, której znaczenie zawarte jest w barwach - czerwień ziemi skontrastowana z bielą postaci to symbol walki i ofiary, niebieskość tła nadaje jej wydźwięk duchowy. Ta barwa była dla malarza także znakiem jego osobistej wolności, którą utożsamiał z bezkresem morza $^{39}$. Dwa lata przed śmiercią Aleksandra Bogena, w 2008 r. w Latrun koło Tel Awiwu, odsłonięto ostatnią rzeźbę autorstwa Pomnik Żydowskich Partyzantów i Bojowników Gett. Jego proste, geometryczne formy odwołujące się do omówionych powyżej rysunkowych i malarskich kompozycji, stanowią zwieńczenie procesu transformacji osobistych doświadczeń w znaki-symbole bohaterstwa w walce o wolność $c^{40}$.

Jak już wspomniałam, dwa kolejne motywy odnoszą się do traumy Holokaustu. To odbicie głębokiego wstrząsu, jakiego doświadczył Bogen w getcie wileńskim podczas jego likwidacji, uczestniczący wówczas w tajnej akcji wyprowadzania inteligencji i członków FPO z getta, będąc bezsilnym świadkiem brutalnego wypędzania ludzi z domów, zabijania opornych czy wreszcie selekcji, podczas których starcy, kobiety i dzieci byli przeznaczeni na śmierć.

Pierwszy to scena wysiedlenia opatrywana tytułami: Ostatnia rodzina w getcie, Deportacja. Bogen namalował kilka wersji tego przedstawienia, nadając im coraz bardziej duchowy i uniwersalny wymiar. Jego pierwowzorem są dwa dokumentalne rysunki z lat 1943-1944.

\footnotetext{
39 Informację ta uzyskałam od Tali Bogen - wnuczki artysty.

40 Fotografia obiektu: Bogen A., The Jewish Partisans and Ghettos Fighters Memorial Monument in Latrun, https://commons.wikimedia.org/wiki/File:PikiWiki_Israel_19380_Jewish_Patisans_and_Ghetto_fighers_memorial_in_Lat.JPG (dostęp 12.02.2021).
} 


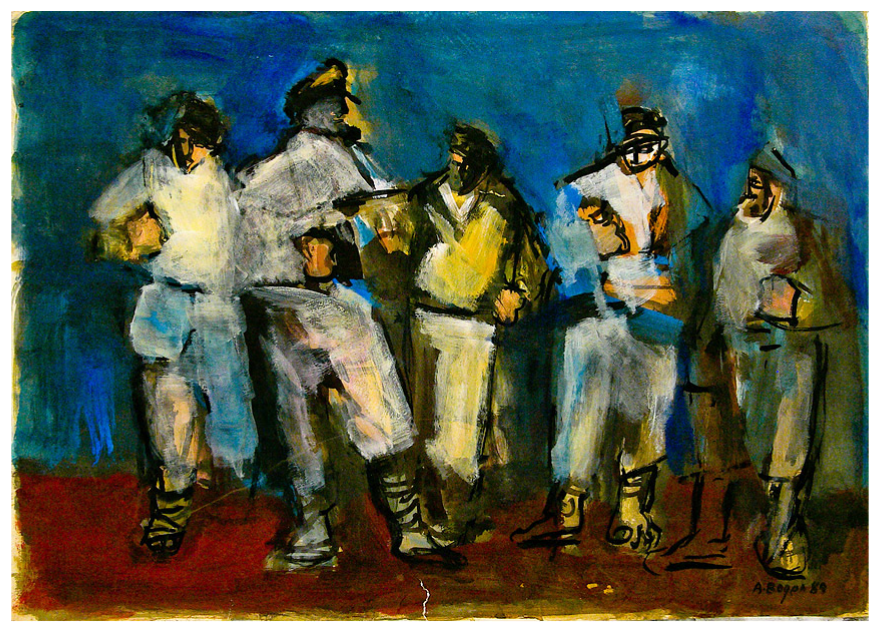

I1. 2. Aleksander Bogen, Partisans / Partyzanci, 1989, gwasz, papier, $51 \times 60 \mathrm{~cm}$. Sygnowany: Bogen 89. Własność Alexander Bogen Foundation, Tel Awiw

Ukazują postacie kobiety trzymającej dziecko na rękach, dziecka chowającego się za matką i przygarbionego starca usiłującego ich osłonić przed uderzeniami esesmańskiego pejcza.

Drugi to wizerunek wychudzonej, bezbronnej dziewczynki trzymającej szmacianą lalkę. Artysta do końca życia pamiętał tę dziewczynkę, której nie mógł pomóc, choć miał w rękach broń i był żołnierzem. Wraz z upływem czasu ta postać stała się uniwersalnym znakiem Zagłady w jego malarstwie.

W odniesieniu do motywu „ostatniej rodziny” dochodzi do podobnego procesu sublimacji jak w przypadku ,partyzantów”. Jego pierwsza olejna wersja - praca dyplomowa z 1947 roku - jest pełna grozy. Malowana w zimnej, ciemnej tonacji szarości i czerni przełamanej brązami. Ciemne sylwetki wypędzanych i atakujących ich esesmanów kontrastują z chłodną, rozbieloną szarością ściany budynku. Mocnym akcentem jest biel ubioru kobiety. Wyrazisty dukt pędzla, niespokojne, czarne linie konturów podkreślają tragizm sceny. Obraz z około 1952 roku cechuje cieplejsza i „lżejsza” kolorystyka wzbogacona o akcenty niebieskości i zieleni. Czarne postaci żołnierzy zestawione są z czystą bielą stroju kobiety i żółtym kolorem ubioru starca, podkreślając wymiar symboliczny użytych barw. Podstawowym znaczeniem bieli jest niewinność. W tradycji żydowskiej oznacza także żałobę i nadzieję na odrodzenie. Ta barwa towarzyszy największemu ze świąt Jom Kipur (Dzień Pojednania), będącego przejściem z czasu pokuty i żalu za grzechy i kończącego stary rok, do nowego, wolnego od grzechu bytowania w kolejnym roku. Żółty kolor w twórczości Bogena odpowiada sile życia. Jest znakiem słońca i pustyni, którą ukochał. Ten schemat kolorystyczny powtarza się w kolejnych reprezentacjach motywu, ograniczonych już tylko do czworga jego bohaterów - matki z dwójką bądź jednym dzieckiem i starego mężczyzny. Artysta stopniowo dokonywał również zmian ich wyglądu, tak by nawiązać do kanonu przedstawień Świętej Rodziny, nadając mu tym samym wymiar uniwersalny i ekumeniczny zarazem. W Deportacji z 1996 roku ten związek jest wyraźnie widoczny zarówno w konfiguracji grupy, jak i ubiorze postaci. Forma i kolorystyka obrazu są wysublimowane - linie konturów delikatne, 
barwy czyste - typowe dla innych dzieł Bogena z tego okresu. Dominuje w nim harmonijna gama świetlistych czerwieni - oznaczających ofiarę Holokaustu, biblijną ofiarę całopalną i wreszcie ofiarę Chrystusa. Suknia kobiety tulącej dziecko utrzymana jest w jasnej czerwieni z akcentami żółcieni przechodzących w oranże chusty okrywającej jej głowę. Mocnym akcentem jest niebieska barwa okrywającego ją szala podkreślająca jej związek z postacią Najświętszej Marii Panny i duchowy charakter sceny.

W 2000 r. Bogen jeszcze raz namalował ten temat, tym razem nadając mu tytuł Rodzina (il. 3). Część centralną kompozycji zajmują trzy, syntetycznie ujęte, postacie - mężczyzny, kobiety i dziewczynki. Dwoje dorosłych jest ubranych w tradycyjne arabskie tuniki, ich głowy okrywają chusty o długich, spływających na ramiona rogach. Dolna część obrazu oraz sylwetki ludzi skonstruowane są z dużych plam bieli, zieleni, błękitu, ugrów, z mocnymi akcentami plam czerni wywołującymi uczucie niepokoju. Górną część kompozycji wypełnia jasny, gładki błękit pogodnego nieba. Na dole, po lewej stronie wyłania się z cienia szczeliny skalnej dziewczynka trzymająca w ręce lalkę. Jej postać, określona czarnymi liniami konturów, utrzymana w zimnej tonacji granatów i zieleni przełamanych szarością, stanowi bolesne memento. To cień Zagłady stale towarzyszący Ocalonemu, nawet po wielu latach szczęśliwego i twórczego życia. Czerń i granat rozdzierające błękit i zieleń odrodzenia to także znaki zagrożenia nowym Holokaustem - ludobójstwem, wojnami, katastrofami ekologicznymi.

Motyw dziewczynki z lalką pojawia się także w kilku innych obrazach Bogena. Są to na poły abstrakcyjne sceny symboliczne o przesłaniu odnoszącym się do sfery głębokich, psychicznych i duchowych doświadczeń. Jak już wspomniałam, jej pierwsze wizerunki powstały w $1943 \mathrm{r}$. Ich graficzne odpowiedniki pojawiają się w tekach publikowanych w latach pięćdziesiątych XX w. oraz w ilustracjach do tomików poezji Mordechaja Gebirtiga i Abrahama Sutzkevera wydawanych w Izraelu w 1997 i 2002 r. Do najbardziej interesujących dzieł, w których Ofiara Holokaustu splata się znaczeniowo z Ofiarą Ukrzyżowania należą dwie prace.

Pierwsza, zatytułowana Sacriface (Ofiara, 1983) ukazuje Chrystusa na krzyżu. Tło utrzymane jest w zimnej, nasyconej tonacji zieleni i czerni. Świetliste, jasnozielone ciało Chrystusa wyłania się z niego niczym symbol odrodzenia ${ }^{41}$. U stóp krzyża, z lewej strony, widnieje czerwona sylwetka lalki stanowiącej znak Zagłady. W 1992 roku Bogen stworzył inną wersję przedstawienia opatrzoną znamiennym tytułem: One thing befalls them both / Ecclesiastes (To samo spotkało ich oboje/ Eklezjasta) (il. 4). Niebieska postać Jezusa rozpięta jest na czarnym krzyżu umieszczonym na tle błękitnej ściany zbudowanej z płyt kamiennych o nieregularnych kształtach. Jej błękit przecina w połowie pozioma szczelina ziemi, której geometryczne formy malowane są w ugrach przełamanych czernią z niewielkimi akcentami jaskrawej czerwieni. Wzdłuż prawej krawędzi obrazu widnieje napis w j. hebrajskim: kohelet.

\footnotetext{
41 Postać Chrystusa jako symbolu odrodzenia narodu żydowskiego pojawia się w twórczości artystów awangardowych, w Polsce m.in. w pracach łódzkiej grupy „Jung Jidysz”. Wydaje się, że najbliższym Bogenowi źródłem inspiracji było malarstwo Chagalla. W pracach Bogena, także tych, które nie są przedmiotem niniejszego artykułu, odnaleźć można wiele odniesień do „,chagallowskiej” ikonografii, w szczególności do postaci Chrystusa jako znaku ofiary Zagłady i odkupienia. Więcej na ten temat zob. m.in.: A. Mendelsohn, Behold the Man: Jesus in Israeli Art, Jerusalem, 2017; M. Rajner, The Iconography of the Holy Family in Chagall's 1909-1910 Works, w: Interaction between Judaism and Christianity in History, Religion, Art and Literature, red. M. Poorthius, J. Schwartz, J. Turner, Leiden, Holland 2009, "Jewish and Christian Perspectives Series", t. 17, s. 495-507; M. Rajner, Chagall's Jew in Bright Red, "Ars Judaica, The Bar-Ilan Journal of Jewish Art", 2008, t. 4, s. 61-80.
} 


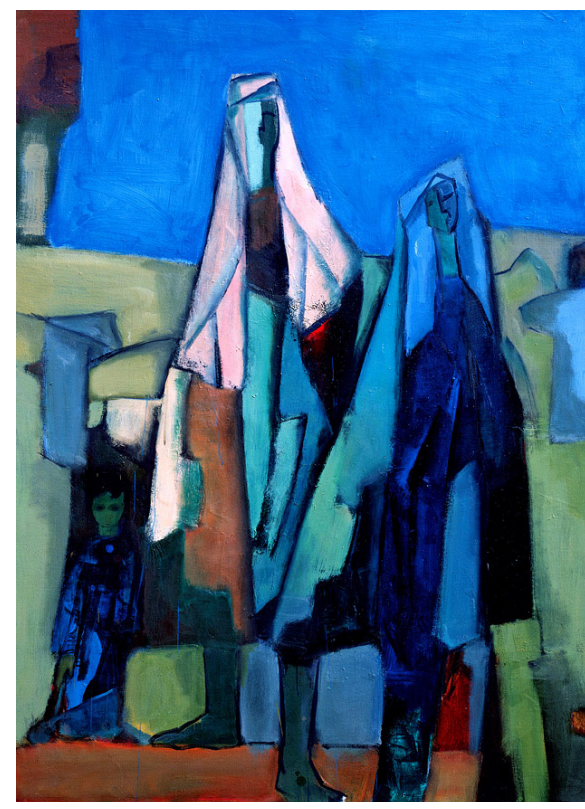

I1. 3. Aleksander Bogen, Family / Rodzina, 2000, olej, płótno, $162 \times 120$. Własność Alexander Bogen Foundation, Tel Awiw

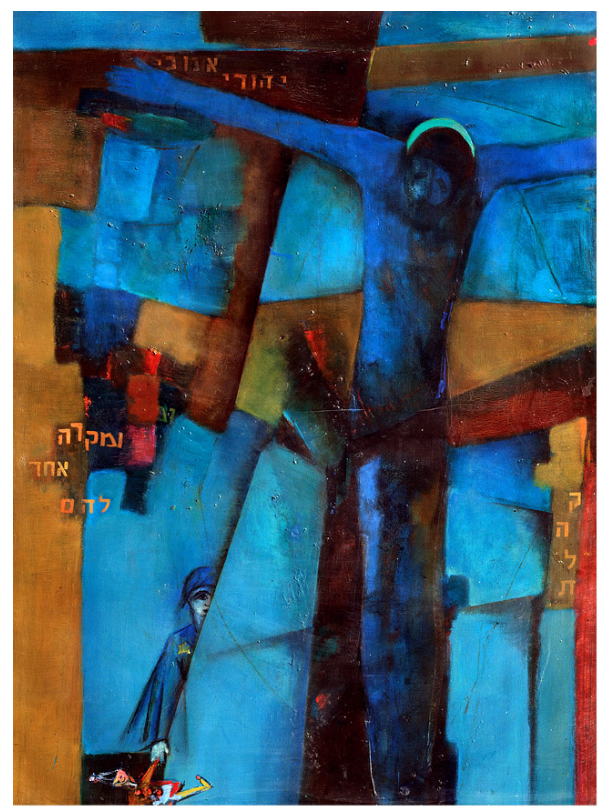

I1. 4. Aleksander Bogen, One thing befalls them both (Ecclesiastes) / To samo spotkato ich oboje (Eklezjasta), 1992, olej, płótno, $162 \times 120$. Własność Alexander Bogen Foundation, Tel Awiw

Po lewej stronie kompozycji, u dołu szczeliny umieszczony jest hebrajski napis: wamikra echad lahem (jeden przypadek dla nich). Pod nim, zza bloku skalnego wyłania się niebieska dziewczynka z kolorową, czerwono-białą lalką w ręce. Obraz ten można uznać za podsumowanie rozważań Bogena nad tragedią Holokaustu i jego odniesieniami we współczesnym świecie. Dokonał w nim symbolicznego zespolenia Zagłady z ofiarą Chrystusa poprzez umieszczenie ich symboli w jednej metafizycznej sferze, zastosowanie tej samej barwy określającej obie postacie, bieli i czerwieni lalki oraz zieleni nimbu Jezusa jako znaków ofiary i nadziei odrodzenia oraz dodanie inskrypcji objaśniającej sens kompozycji. Dominacja niebieskiej gamy barwnej przenosi traumę Ocalonego w sferę doświadczenia duchowego.

Ostateczna transformacja tragicznych doświadczeń malarza dokonała się w jednym z ostatnich jego dzieł - tryptyku Apokalipsa z lat 1994-2000. Abstrakcja skomponowana jest z geometrycznych, pionowych kształtów przywodzących na myśl motyw Partyzantów. Zawieszone w niebieskiej przestrzeni, gładkiej i świetlistej, są swego rodzaju pęknięciami, z których wydobywają się wspomnienia wojenne. Utrzymane w chłodnych, przełamanych szarością i czernią zieleniach i niebieskościach, wypełnione są mrocznymi cieniami postaci, trupimi czaszkami, fragmentami szkieletów, pojawia się w nich także sylwetka dziewczynki i jej czerwona lalka oraz postać Ukrzyżowanego. Pośrodku widnieje mocny akcent jaskrawej żółcieni. To monumentalne dzieło obrazuje nie tylko ogrom Holokaustu, także nieuchronność śmierci każdej żywej istoty i zagrożenia, jakie niesie ze sobą cywilizacja. Jednak, 
dzięki zastosowaniu żółtej barwy, pozostawia cień nadziei na odrodzenie w niekończącym się cyklu życia.

Podsumowując analizę metamorfozy doświadczenia Zagłady i jej wizualnego odzwierciedlenia w omówionych powyżej dziełach Aleksandra Bogena, warto zauważyć, że występuje w nich gama kolorystyczna ograniczona do kilku nasyconych i czystych barw. Są to: biel, czerwień, zieleń, niebieski, żółcień. W tradycji żydowskiej mają one wielorakie znaczenia symboliczne. W powiązaniu ze światem natury czerwień i żółcień reprezentują ogień oraz siłę i sąd, biel jest kolorem wody, życzliwości i dobroci, niebieski oznacza powietrze, wspaniałość i miłosierdzie ${ }^{42}$. W oparciu o najważniejsze źródło pisane judaizmu - Tanach (Biblia Hebrajska, hebr. skrót utworzony od nazw poszczególnych części kanonu: Tora - Pięcioksiąg Mojżeszowy, Newiim - Prorocy, Ktuwim - Pisma), otrzymują znaczenia duchowe. Biel symbolizuje absolutną czystość Boga, oczyszczenie z grzechu, odkupienie, a także zwycięstwo Stwórcy nad mocami zła. Czerwień oznacza krew, grzech i pokutę, ale też siłę życia, zaś w powiązaniu z postacią Chrystusa - ofiarę i odkupienie. W tym kontekście zastosowanie tych dwóch barw w motywie lalki w obrazie One thing befalls them both / Ecclesiastes wzmacnia połączenie ofiary Zagłady z ofiarą Chrystusa, która niesie odkupienie. Niebieski symbolizuje chwałę tych, którzy są wierni przykazaniom, wodę życia, a także obecność Boga w niebiosach. Zieleń to kolor wegetacji, odrodzenia, nieśmiertelności, cykliczności natury i jej obfitości oraz nadziei. Żółcień w tradycji uważany jest za połączenie bieli i czerwieni. Określa również barwę złota. Reprezentuje blask i chwałę stworzenia - emanacji boskiej. W Kabale (mistycyzmie żydowskim) powiązany jest z Szechiną (hebr., obecnością Bożą). Stanowi symbol siły życia, radość z obecności Boga, także Jego świętość i splendor ${ }^{43}$. W kontekście historycznym ma jednak drugie, negatywne znaczenie związane ze znakiem naznaczenia i wykluczenia - żółta łatą i gwiazdą Dawida w tej barwie, którą Żydzi byli zmuszeni nosić na ubraniach w czasie drugiej wojny światowej, m.in. w getcie łódzkim. W tym kontekście akcenty żółci we wspomnianym powyżej tryptyku Apokalipsa mogą wnosić pewną ambiwalencję znaczeniową - stanowiąc, obok nadziei na odrodzenie dzięki obecności Boga i sile życiowej płynącej z boskiej obecności, także cień obawy i symbol zagrożenia nietolerancją i przemocą mającym swoje źródło w ludzkiej ignorancji.

Aleksander Bogen w nowej ojczyźnie narodził się na nowo. Poświęcił się w sztuce tym zagadnieniom, które były najbliższe jego silnej i pełnej optymizmu osobowości - studiowaniu przejawów piękna i siły natury i przekładaniu tych jakości w mieniące się kolorami obrazy. Choć wracał do doświadczeń Holokaustu, dzięki swojemu talentowi, mistrzowskiemu opanowaniu warsztatu, a także mocy przemiany, jaką dają upływ czasu i twórczość artystyczna potrafił je przekształcić w doświadczenie duchowe o uniwersalnym charakterze. „Nie jestem malarzem Holokaustu - mówił o sobie - jestem malarzem, który przeżył Holokaust”"44.

\footnotetext{
42 Barwy te odpowiadają także aniołom i postaciom biblijnym: czerwień - Gabrielowi, biel - Michałowi / Abrahamowi, niebieski - Urielowi.

43 W tradycji żydowskiej poszczególne barwy przypisane są także do 12 plemion Izraela, w Kabale - dziesięciu sefirotom - naczyniom zawierającym boskie jakości, które stanowią podstawę świata i stworzenia.

44 A. Bogen, Z. Amishai-Maisels, Alexander..., s. 217.
} 


\section{Bibliografia}

Amishai-Maisels Z., The Influence of the Holocaust on the Visual Arts, Oxford 1993.

Bogen A., Amishai-Maisels Z., Alexander Bogen, Israel 2005.

Cała A., Ochrona bezpieczeństwa fizycznego Żydów w Polsce powojennej. Komisje Specjalne przy Centralnym Komitecie Żydów w Polsce, Warszawa 2014.

Ćwiakowska A., Spacer z Aleksandrem Bogenem, „Nowiny Kurier”, Tel Awiw 1948, z 28 XII, s. 3.

Datner H., Po Zagładzie. Społeczna historia żydowskich domów dziecka, szkót, kót studentów w dokumentach Centralnego Komitetu Żydów w Polsce, Warszawa 2016.

Engelking B., Na łace popiołów: ocaleni z Holokaustu, Warszawa 1993.

Engelking B., Zagłada i pamięć: doświadczenie Holokaustu i jego konsekwencje opisane na podstawie relacji autobiograficznych, Warszawa 1994.

Epsztein T., Wstep, w: Inwentarz Archiwum Wydziału Statystyki i Ewidencji Centralnego Komitetu Żydów w Polsce 1945-1950, Warszawa 2019, s. 2-13.

Gadowska I., Żydowscy malarze w Łodzi w latach 1880-1919, Warszawa 2010.

Gelbart S., Wystawa obrazów J. Muszkietowej i Al. Bogena, „Mosty”, 1948, nr 32, s. 3.

Gelbart S., Zbiorowa wystawa plastyków żydowskich, „Mosty - Nasze Słowo”, 1949, nr 41, s. 7.

Grabski A., Centralny Komitet Żydów w Polsce (1944-1950). Historia polityczna, Warszawa 2015.

Grygiel T., Wystawa zbiorowa Grupy Artystów Żydów w Łodzi, „Nasze Słowo”1948, nr 2, s. 6.

Grynberg M., Żydowska spółdzielczość pracy w Polsce w latach 1945-1949, Warszawa 1986.

H., Zbiorowa wystawa plastyków żydowskich, „Mosty”, 1949, nr 41, s. 7.

Hornowa E., Powrót Żydów polskich z ZSRR oraz dziatalność opiekuńcza Centralnego Żydowskiego Komitetu Żydów w Polsce, „Biuletyn Żydowskiego Instytutu Historycznego”, 1982, nr 1-2, s. 105-122.

Kacprzak D., Kolekcje ziemi obiecanej: zbiory artystyczne łódzkiej burżuazji wielkoprzemysłowej w latach 1880-1939, Warszawa 2015.

Kendziorek P., Program i praktyka produktywizacji Żydów polskich w działalności CKŻP, Warszawa 2016.

Kersten K., Repatriacja ludności polskiej po II wojnie światowej, Wrocław-Warszawa-Kraków-Gdańsk 1974.

Malinowski J., Malarstwo i rzeźba Żydów polskich w XIX i XX wieku, Warszawa 2000.

Malinowski J., Katalog dzieł artystów polskich $i$ żydowskich z Polski w muzeach Izraela, Warszawa 2018.

Melchior M., Zagłada a tożsamość, Warszawa 2004.

Mendelsohn A., Behold the Man: Jesus in Israeli Art, Jerusalem 2007.

Muzeum Żydowskiego Instytutu Historycznego. Zbiory artystyczne, Warszawa 1995.

Olejnik L., Polityka narodowościowa Polski w latach 1944-1960, Łódź 2003.

„Opinia”, 1947, nr 11, s. 9.

Piątkowska R., Między Ziemiańska a Montparnasse’em, Warszawa 2004.

Rajner M., Chagall's 'Jew in Bright Red' "Ars Judaica: The Bar-Ilan Journal of Jewish Art", 2008, t. 4, s. 61-80.

Rajner M., The Iconography of the Holy Family in Chagall's 1909-1910 Works, w: Interaction between Judaism and Christianity in History, Religion, Art and Literature, red. M. Poorthius, J. Schwartz, J. Turner, Leiden, Holland 2009, "Jewish and Christian Perspectives Series", t. 17, s. 495-507.

Rosner A. M., Obraz społeczności ocalałych w Centralnej Kartotece Wydziału Ewidencji i Statystyki CKŻP, Warszawa 2018.

Rykała A., Przemiany sytuacji społeczno-politycznej mniejszości żydowskiej w Polsce po drugiej wojnie światowej, Łódź 2007.

Segev T., Siódmy milion. Izrael - piętno Zagłady, tłum. B. Gadowska, Warszawa 2012. 
Styrna N., Zrzeszenie Żydowskich Artystów Malarzy i Rzeźbiarzy w Krakowie 1931-1939, Kraków 2009. Tarnowska M., Aleksander Bogen (1916-2010). Przemiany postawy w świetle twórczości i krytyki artystycznej z lat 1945-1951, w: Oblicza utopii, obłudy i zaktamania, t. 2, red. W. Łysiak, Poznań 2014, s. 107-118.

Tarnowska M., Artyści żydowscy w Warszawie 1939-1945, Warszawa 2015.

Tarnowska M., Żydowskie środowisko artystyczne w Warszawie w latach 1945-1949, „Pamiętnik Sztuk Pięknych. Sztuka Polska 1945-1970”, 2015, nr 9, s. 33-61.

Tarnowska M., Jewish Artistic Revival in Lower Silesia (Poland) 1945-1949: Art and Activity in the Light of Source Materials and Art Criticism, „Kwartalnik Historii Żydów”, 2020, nr 2, s. 425-450.

Wilno i cały świat w malarstwie Rafała Chwolesa, oprac. M. Supruniuk, M. Tarnowska, Toruń 2006, http://www.muzeum.umk.pl/pdf/chwoles.pdf (dostęp 10.10.2020).

Zarys działalności CKŻP za okres od 1 stycznia do 30 czerwca 1946, Warszawa 1947.

Zientara M., Krakowscy artyści i ich sztuka w latach 1939-1945, Kraków 2013.

Żbikowski A., Są Społeczny przy CKŻP. Wojenne rozliczenia społeczności żydowskiej w Polsce, Warszawa 2014.

Żółkiewska A., Zerwana przeszłość. Powojenne środowisko żydowskiej inteligencji twórczej. Pomoc materialna i organizacyjna ze strony CKŻP, Warszawa 2017.

Żydzi w Polsce. Obraz i stowo, red. M. Rostworowski, Warszawa 1993.

Źródła archiwalne

Archiwum ŻIH, ŻTKSP nr 361/I, Korespondencja z 13 XI 1948 w sprawie wystawy Bogena w Łodzi. Archiwum ŻIH, ŻTKSP nr 361/II, Podanie A. Bogena do Komisji Opieki Społecznej CKŻP z X 1947.

Źródła internetowe:

Alexander Bogen Foundation, Alexander Bogen, http://alexanderbogen.com/ (dostęp 20.05.2020).

Alexander Bogen Collection at the United States Holocaust Memorial Museum in Washington D. C., https://collections.ushmm.org/search?q=Bogen\%2C\%20Alexander.\&search_field=Subject (dostęp 15.03.2020).

Bogen A., The Jewish Partisans and Ghettos Fighters Memorial Monument in Latrun, https:/commons. wikimedia.org/wiki/File:PikiWiki_Israel_19380_Jewish_Patisans_and_Ghetto_fighers_memorial_in_Lat.JPG (dostęp 12.02.2021).

Bogen (Katzenbogen) A. (Shura), The Onset of the Partisan Units in the Forest of Naroch, http://www. eilatgordinlevitan.com/vilna/vilna_pages/vilna_stories_alexander_bogen.htm (dostęp 20.05.2020).

Merav J., Sternin M., Interview with Alexander Bogen, Survivor and Artist, https://www.yadvashem. org/articles/interviews/alexander-bogen.html (dostęp 22.09.2020).

The Pen and the Sword, https://www.yadvashem.org/yv/en/exhibitions/bogen/index.asp (dostęp 18.02.2020). 